\title{
Sensory garden in the school area
}

\author{
Margot Dudkiewicz \\ https://orcid.org/0000-0002-3762-6192 \\ margotdudkiewicz@o2.pl
}

\section{Patryk Krupiński}

patrykrupinski@gmail.com

\section{Magdalena Stefanek}

magdalena.stefanek@o2.pl

\section{Marcin Iwanek}

https://orcid.org/0000-0002-2113-1101

marcin.iwanek@poczta.umcs.lublin.pl

Department of Landscape Architecture, Faculty of Horticulture and Landscape Architecture, University of Life Sciences in Lublin

\begin{abstract}
School gardens play an important role in learning about nature by children and young people. Lessons conducted in the open air surrounded by greenery develop the interests of pupils, who can observe particular stages of plant development and seasonal changes. Classes in biological and chemical subjects, art, music, Polish and English can be conducted in school gardens. The study presents selected case - concept of a land development at the Elementary School in Stasin (Lublin province) converting the current school environment into a sensory garden. The novel project will meet the diverse needs of children, allow for their proper mental and physical development, and allow teachers to conduct creative classes. The project created zones of senses, dividing them into the zone of sight, hearing, touch, smell and taste. In addition, representative, educational, sport and recreational zones were distinguished in front of the building. Consistency of the whole assumption is provided by attractive plantings and unified small architecture.
\end{abstract}

Keywords: school garden, sensory garden, child, Stasin in Konopnica commune

\section{Introduction}

The proper development of a young person consists of many interrelated factors, which are aspects related to family and social life, character and life experience. School, which is the first place for young people to prove themselves as a separate unit, also plays significant role in child's development. School is a place, where a child experiences his/her first successes, failures, acquires the necessary knowledge and learns to cooperate with the surrounding world. Let's consider how not only the educational institution and its qualified staff, but its surroundings - i.e. garden, nature and landscape - influences on the child's development. Sensitivity and social responsibility acquired by young people over a dozen years of study, are also worth considering.

The space we live in, affects people in different ways: it can both help and disturb someone's needs. We can freely design and adapt it to own preferences. Greenery has large impact on ourselves, our mood and interpersonal interactions (Sobczyńska 2014). Vegetation is responsible for noise suppression, temperature drop and humidity increase during the hot season, it can also absorb harmful gaseous and dust substances creating somehow a type of air filter. Due to the presence of animated nature, it is easier to read the space, to adapt to it and find oneself in it. 
The school garden is classified among children's garden complexes. It is the space developed with appropriate devices designed for children's play and leisure. The main task of school gardens is to shape the right conditions favoring mental and physical development of pupils (Kruszko 2013). Jordan gardens were the prototype of gardens for children and youth. The first such assumption was made in Krakow in 1889 on the initiative of dr. Henryk Jordan. The children's garden covered an area of 9 hectares and included places for games, plays and education, intended for various age groups of young people (Majdecki 2008). The creator of the $20^{\text {th }}$ century sensory garden idea is considered to be the German scientist Hugo Kukelhaus - the originator of the Field of Sensory Experiments, that is an educational park in Nuremberg (Dąbski and Dudkiewicz 2010).

In a sense, any type of garden can be referred to as a sensory garden, because they are perceived by users with all their senses - sight, taste, touch, smell and hearing. At the same time, the eye plays a key role, suppressing the perception of other stimuli that make the observed image more attractive or destroy. Visual reception is so strong that we focus all our attention on it. Hence, we call the sensory garden an assumption that intentionally introduces the dominance of extra-visual senses (Pawłowska 2008).

The scope of this research included a review of literature on the subject and the concept of a model solution for land development at the Elementary School in Stasin in Konopnica commune (Lublin province). The project involves improving technical condition and aesthetics of the pavement, providing the facility with small architecture objects, improving condition of existing vegetation and making new plantings useful in children's education and development.

\section{Material and methods}

The paper is of review and design nature. It used inhouse and field research as well as design work. A brief overview of the subject literature is provided. Field studies were conducted in 2017. They consisted of a detailed dendrological inventory and photographic documentation of the object. Results were collected in the form of a table and an inventory map. The table includes: Polish and Latin names of plants, perimeter of the tree trunk / shrub area in $\mathrm{m}^{2}$, diameter of the tree crown, height of specimens, as well as comments on the state of health and recommendations for plant care. Measuring tapes and rangefinder were used in measurements. The circumference of the trunk was taken as the value of the circumference measured at a height of $130 \mathrm{~cm}$ from the ground surface tangent to the trunk. The diameter of the crown was measured based on the measurement of the furthest parts of the crown of a given tree. Comments on general condition of species included: shape of the crown, statics of the trunk, health and aesthetic values of the species, as well as age of the tree, estimated share of deadwood in the total mass of the specimen, usefulness of form and legitimacy in arranging the new shape of the assumption. Then, nature, functional, scenic and communication analyses of the object were made.

Cataloguing and analysis showed that the area next to the elementary school in Stasin is naturally interesting due to large share of woody vegetation and significant proportion of biologically active area. The attractiveness and aesthetics of the assumption is not sufficient, and the area does not fulfill the designated representative, useful and practice functions. The lack of a general program of establishment, accidental plantings and insufficient quantity and quality of appropriate small architecture as well as places for active and passive rest for all users of the object makes the place only surroundings, and its natural and educational values are lost. The conceptual design provides for the creation of zones corresponding to specific functions, opening to the needs of users. Sensory garden will meet the needs of children, allow them for a proper mental and physical development. During the development of the project, attention was paid to the selection of appropriate vegetation, small architecture and pavement to ensure the highest level of safety at the school.

\section{Sensory gardens as a place of child's learning and development}

From the first years, a child is interested in nature. Everything that makes a sound, moves, changes, rises or disappears, is colorful or simply alive, is close to the child. Several-year-olds feel the joy of communing with nature; it is not their duty, but pleasure; they absorb the surrounding world and derive motivation from fulfilling their tasks (Frątczak and Frątczak 1991). Activity in a garden provides children with happiness and contentment, 
satisfies the need for movement and allows them to understand the world. Children working in the garden from an early age learn to cooperate in a group, further developing the pro-ecological views. The will is especially strengthened when children are satisfied with their work. By taking care of the garden, children bring order into their world, develop intellectual, social and physical skills. They gain greater confidence, speak properly, count better, learn what value and responsibility are (Klichowska 2013).

Man has naturally developed need to connect with nature - Wilson called this phenomenon the biophilia theory' (1993). It shows genetic tendencies of a man, created over the years of evolution, to a positive response to the natural environment, of which our ancestors formed an integral part for almost $90 \%$ of the human history. Therefore, the young man's contact with nature is so important, and it cannot be replaced by any technical or play equipment. Communing with nature improves memory, develops imagination and creative thinking, increases greed in learning about the world, encourages cognition, improves self-confidence, helps fight stress, and positively affects relationships and communication between children (Nowak 2003). Not complaining about physical ailments, a smaller percentage of children dropping out of pre-school education, lower levels of stress, anxiety or depression among children are just some of the positive aspects of children's participation in the pre-school gardening programs (Choi and Son 2000). Practical contact with nature, fun and learning in the open air, the ability to create space independently under the watchful eye of caregivers is the most important in child's development. It has been proved that the aesthetic, spiritual and psychological value of work in the garden and the very fact of its presence is much more important than the benefits of producing horticultural plants (Relf 1981). Communing with the surrounding world also plays an extremely important role in the process of maturing young people, creates caring behaviors, teaches self-discipline and responsibility, which is important in discovering oneself and helps in achieving the goals set in the future. In this age group, girls showed greater sensitivity; among other groups, these differences are not so clearly marked (Waliczek and Zajiczek 1999). The issue of self-development by drawing from nature is a lot of issues, based on various aspects of life, science and knowledge; these are different disciplines examining the dependence of our well-being on the environmental conditions we live in. One of the segments researching these issues is the development of socio-horticulture, which reveals a new definition of gardening: "gardening is the art and knowledge of the cultivation of flowers, fruits, vegetables, trees and shrubs, which results in mental and emotional development of a man, wealth and health of society, integration" of the garden with the flourish of modern civilization" (Relf 1992). The author refers to both pot plants, indoors, and large-scale park arrangements in that definition of the garden.

Research shows that the therapeutic effect of gardens on children brings benefits in the form of: development of imagination and creativity, increased curiosity of the world and motivation to learn, improved memory, confidence, reduced stress and improved relationships with other children. Results of experiments carried out in South Korea showed that the number of children, who were willing to leave the institution decreased in gardens where the gardening program was introduced. In adolescents, contact with the garden increases self-discipline, responsibility and shapes caring behaviors, which is associated with improved concentration, reduced overcoming difficulties in school and imprudent behavior (Dudkiewicz et al. 2018).

The environment, in which we live, should be a safe refuge - we know changes occurring in plants, we feel the rhythm of their lives, consistent with our rhythm, despite the diversity that prevails in the garden - we feel calm in it. Taking advantage of charms of open areas, we relax, get rid of stress and depression. Plants stimulate our senses of sight and smell, flowers and leaves can be dried, arranged in bouquets, herbs can be used in the cuisine, other parts of plants in the artistic craft. The world of nature opens up unlimited possibilities for cooperation dependent only on our imagination (Etherington 2015). Various types of "creations" of nature, such as cones, stones, feathers, shells, sand and gravel, due to their variety in shapes, sizes or matter from which they are created, are ideal objects for learning through play. Such gardens absorb all senses to better explore the world around us - nature, through simple mechanisms, teach basic laws of physics, chemistry and the effects of nature. It is very important to use natural materials that will allow young people to get to know the world without unnecessary stress, because immediately the impact of man on the environment and the results of his actions are visible. In addition, the user of the sensory garden not only completes his knowledge and learns new things, but also improves concentration, hand-eye coordination, hand motility, calms down, as well as develops empathy, a sense of aesthetics or simply spends time in an attractive place ( Połucha and Kruba 2012).

We find ourselves in public space in different ways and for different reasons. According to Jan Gehl's theory (2013), there are three types of outdoor activity. These may be necessary actions, i.e. going to school, work, 
shopping, waiting for means of transport. Another of the described varieties of activities are optional activities that take place depending on our desire, time and place. The last category is the type of social activities, which depends on the presence of other users of public space, children's games, welcome gestures and conversations. The school and its neighborhood, to which this work was devoted, seems to be a place connecting all types of human interaction with the environment. Therefore, it is very important to properly ensure the diversity and proper functioning of these interactions in a good space.

Whether a given area meets the expectations of users is influenced by many factors. One of them is the designer's awareness of the usefulness of the proposed form, safety and aesthetics. When designing the areas around educational institutions, one should remember basic recommendations, which are e.g. location of both animate and inanimate elements (garden - building), use of prevailing climatic conditions, and adequate sunlight. Location of the assumption in relation to communication arteries is extremely important, as it is the most effective exclusion of air pollution, noise, danger resulting from heavy traffic, as well as appropriate fencing and user protection. In terms of nature, adequate management of field potential also plays a huge role, including soil abundance, or the use of old trees and naturally occurring terrain (Klichowska 2013). The projected number of assumption users also plays a significant role.

\section{The concept of a sensory garden at an elementary school}

The study area is located in the town of Stasin in the suburban area of Lublin, in the Konopnica commune. The elementary school building is located on a plot of $5730 \mathrm{~m}^{2}$ area. The property is surrounded by individual housing and open countryside. The first information about the existence of the school in Stasin dates back to 1817. The current building dates back to 1993, after the previous one burned down in a fire. There is a fenced playground in front of the school. There is a car park on both sides of the square, and a grass pitch was located in the northern part of the area. The area around the object will be intended for children between 6 and 15 years old.

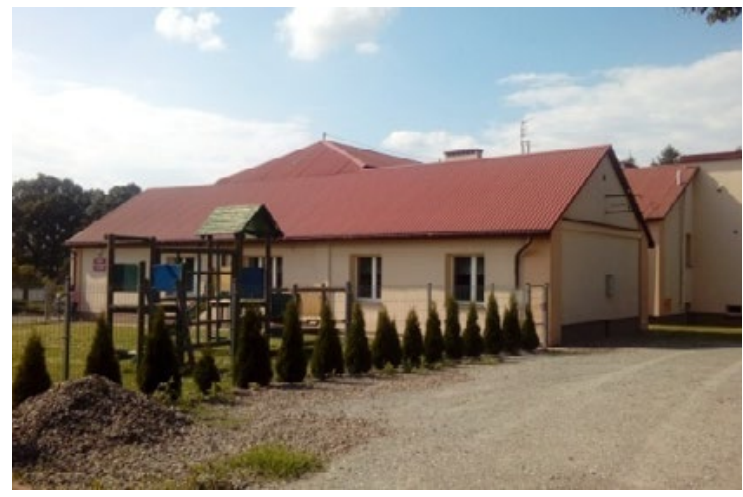

Fig. 3. Building of the Elementary School (by M. Stefanek, 2017)

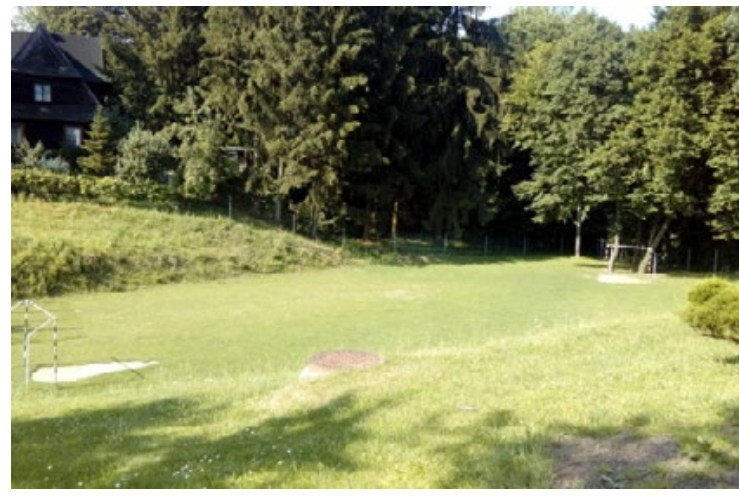

Fig. 4. School playground (by M. Stefanek, 2017)

As a result of a detailed dendrological inventory, it was found that the trees and shrubs found there are in good condition and require only minor care treatments. 160 trees and shrubs were inventoried. In terms of quantity, Thuja occidentalis 'Smaragd' (62 pcs) prevail, Juniperus scopularum 'Blue Arrow' (12 pcs) growing in hedges. In addition, there are: Abies nordmaniana (9 pcs), Juniperus horizontalis 'Limeglow' (7 pcs), Picea pungens (7 pcs), Pinus mugo (6 pcs), Picea abies (5 pcs), Juniperus media (5 pcs.), Thuja occidentalis 'Arnold' (3 pcs), Juniperus communis 'Gold Cone' (1 pcs), and from deciduous plants: Berberis thunbergii 'Aurea' (10 pcs), Berberis $\times$ ottawensis 'Superba' (6 pcs), Spiraea arguta (5 pcs), Tilia mordata (4 pcs of 97, 100, 200 and $235 \mathrm{~cm}$ in circumference), Spiraea japonica (3 pcs), Carpinus betulus (2 pcs of 117 and $118 \mathrm{~cm}$ in circumference), Sorbus aucuparia (2 pcs of 20 and $44 \mathrm{~cm}$ in circumference), Cotoneaster horizontalis (2 pcs), Betula pendula (1 pc), Berberis thunbergii (1 pc), Crataegus laevigata (1 pc of $50 \mathrm{~cm}$ in circumference), Buxus sempervirens (1 pc), Ginkgo 
biloba (1 pc), Liriodendron tulipifera (1 pc), Quercus robus (1 pc of $180 \mathrm{~cm}$ in circumference), Prunus cerasifera (1 pc) and Prunus triloba (1 pc).

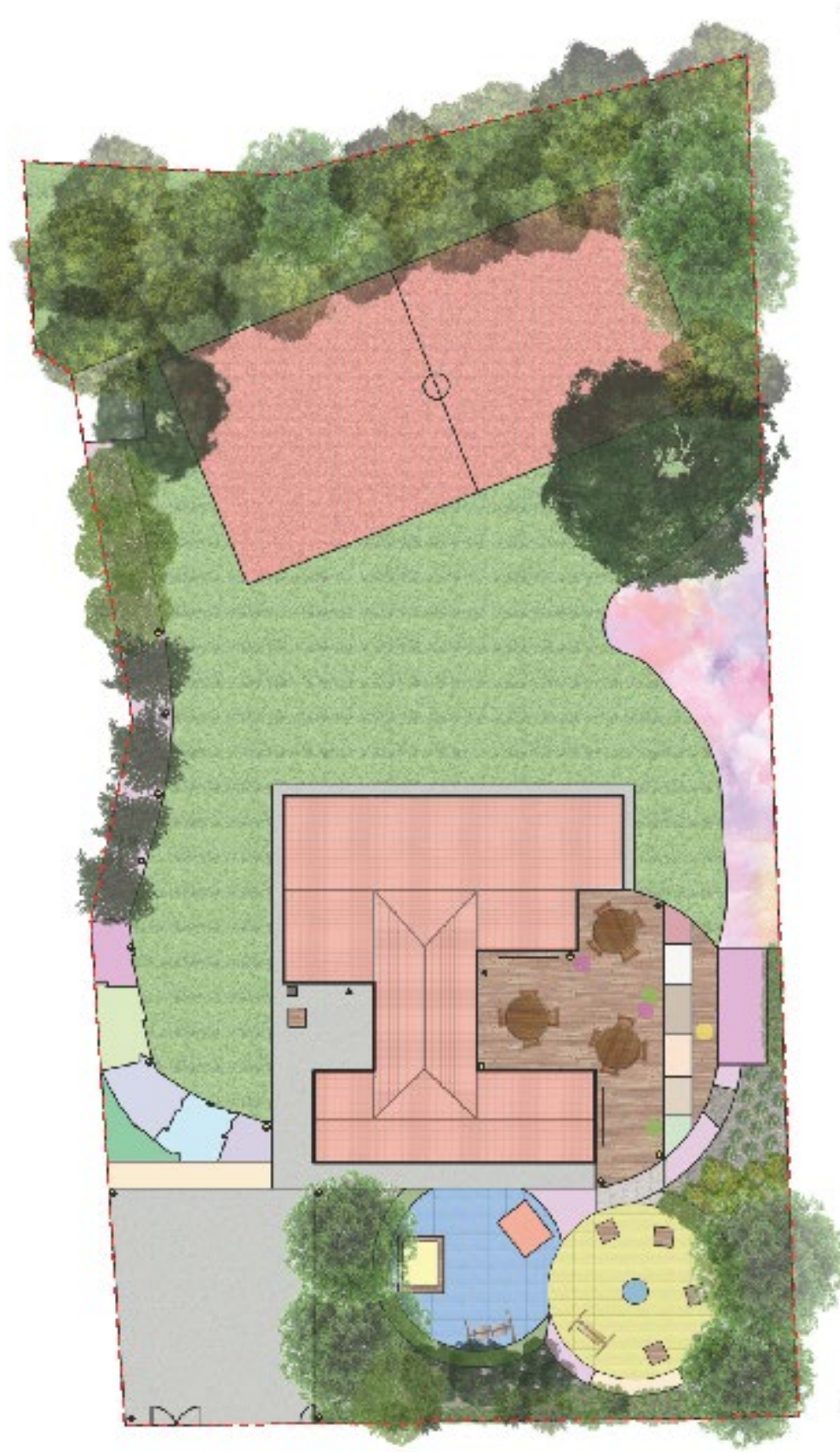

Skala 1:500

Fig. 5. Concept of sensory garden at the Elementary School in Stasin (authors)

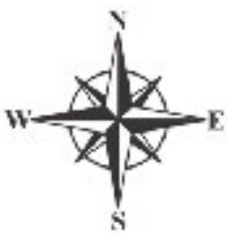

Legenda:

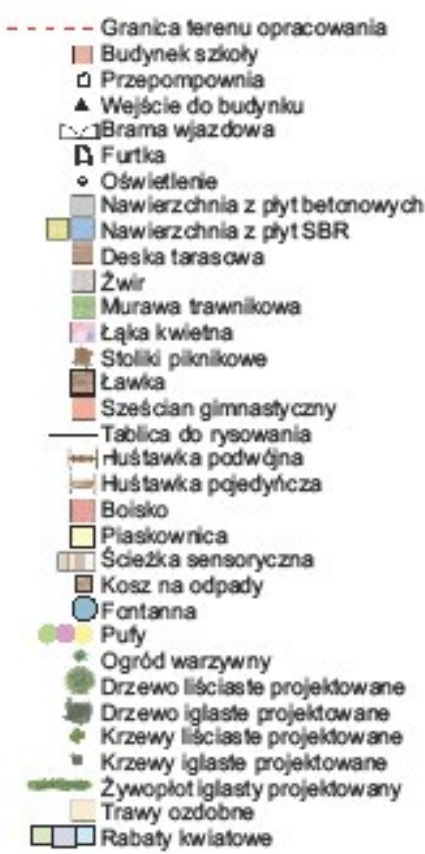

The design includes various types of surface, including cobblestones, gravel, colored bark, lawn turf, sand and wood discs. A flower meadow was designed in the central part of the area. Safe surface made of rubber boards and wooden boards on the terrace have been proposed on the existing playground. Near the playground, there is a zone of sight and touch in the form of colorful rebates. In the eastern part, there is a place 
for a vegetable garden where children can grow plants. In the northern part, the location of the grassy field has been preserved and a hearing zone with tree and shrub plantings has been added. In the western part of the garden, elevated lawns have been designed with plants with special fragrances. The car park is separated from the fragrance zone by a gravel bed with ornamental grasses. There is a gymnastic cube, a tic-tac-toe board, swings and a sandbox on the playground. And the whole area is equipped with benches and bins.

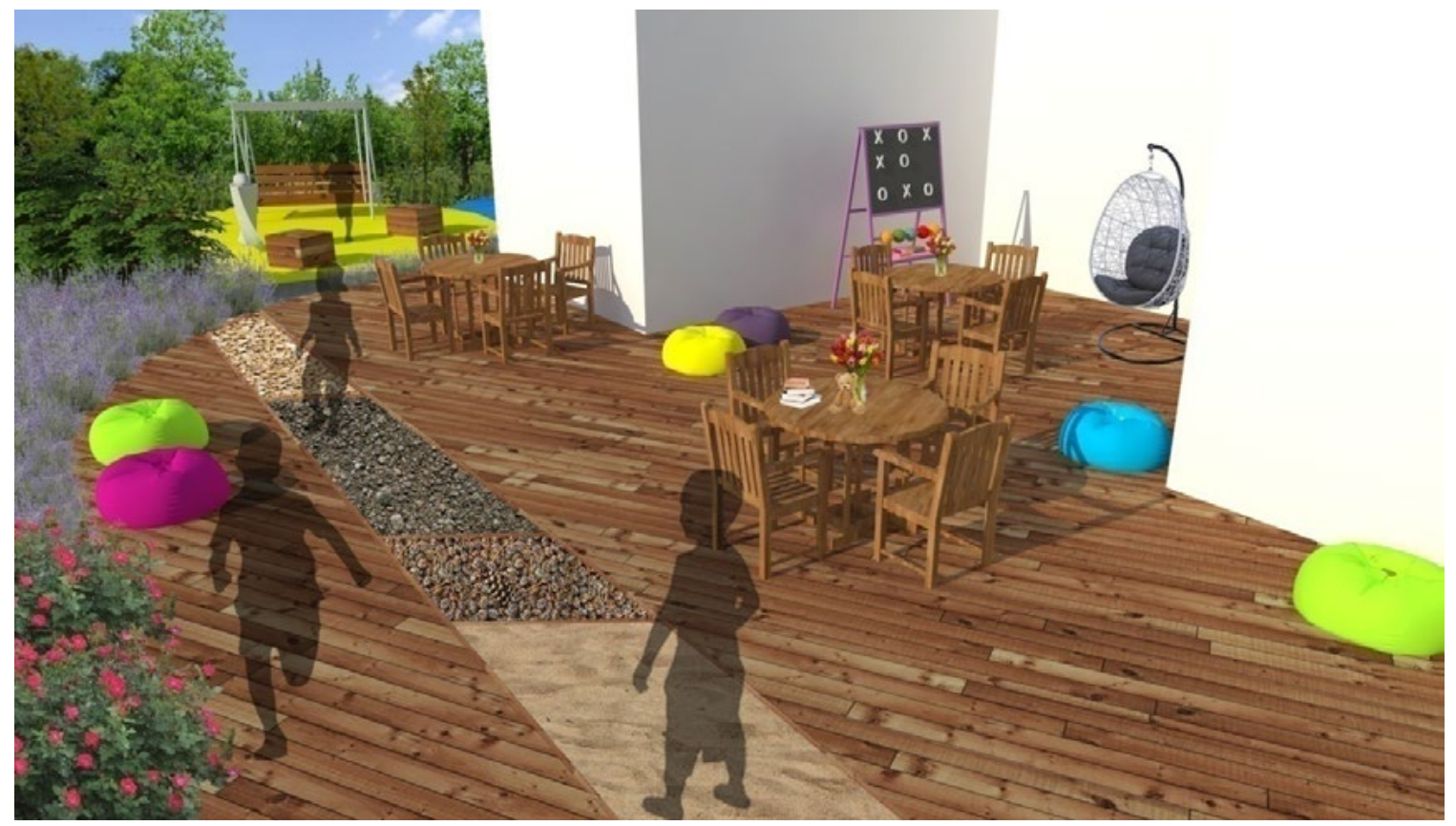

Fig. 6. Concept of sensory garden at the Elementary School in Stasin (authors)

\section{Summary}

A review of the literature and the research results described in it confirms the multifaceted beneficial influence of nature on man. The proprietary model of the park with therapeutic properties has provide support for designers of green areas in the city.

Vegetation performs various functions, from ecological through isolating, health, didactic to aesthetic and it is an integral part of the environment we function in. The proposed space will meet the needs of different age groups of pupils and provide a safe and friendly space for learning and relaxing with the use of sensory plants as well as elements and devices for sensory integration.

\section{Bibliography}

[1] Bańka A. 2002. Społeczna psychologia środowiskowa. WN Scholar, Warszawa.

[2] Choi Y. A., Son K. C. 2000. Development and effect of horticultural therapy program for children. Horticultural therapy for disabled person and children. Korean Horticultural Therapie Association, Seo - Won Books, Seul, Korea.

[3] Dąbski M., Dudkiewicz M. 2010. Przystosowanie ogrodu dla niewidomego użytkownika na przykładzie ogrodów sensorycznych w Bolestraszycach, Bucharzewie i Powsinie. Teka Komisji Architektury, Urbanistyki i Studiów Krajobrazowych PAN oddz. w Lublinie 6: 7-17.

[4] Dudkiewicz M., Pudelska K., Parzymies M., Durlak W. 2018. Rola hortiterapii i bukieciarstwa w leczeniu dzieci i dorosłych. Kosmos 4:813-821. 
[5] Etherington N. 2015. Gadrening of children with Autism spectrum Disorders and Special Educational Needs, Jessica Kingsley Publishers, London.

[6] Frątczak E., Frątczak J. 1991. Kącik przyrody w wychowaniu przedszkolnym, Wydawnictwo Szkolne i Pedagogiczne, Warszawa.

[7] Gehl J. 2013. Życie między budynkami. Użytkowanie przestrzeni publicznych. Wydawnictwo RAM, Kraków.

[8] Klichowska A. 2013. Architektura i funkcje ogrodu przedszkolnego w opiniach nauczycieli. Uniwersytet im. Adama Mickiewicza w Poznaniu, Poznań.

[9] Majdecki L. 2008. Historia ogrodów. Wydawnictwo Naukowe PWN, Warszawa

[10] Nowak J. 2003. Rośliny ozdobne - możliwości rozwoju produkcji i oddziaływania na jakość życia. Folia Hortic. Suppl. 1: $29-31$.

[11] Pawłowska K. 2008. Ogród sensoryczny. Politechnika Krakowska, Instytut Architektury Krajobrazu, Kraków.

[12] Połucha I., Kruba M. 2012. Możliwości edukacji w przestrzeni ogrodowej. Olsztyn.

[13] Relf P.D. 1981. Therapy and rehabilitation through horticulture. Chronica Horticulturae 21(1): 1-2.

[14] Relf P.D. 1992. Human issue in horticulture. Hort Technology 2(2): 159-171.

[15] Sobczyńska K. 2014. Zieleń jako element współczesnego miasta i jej rola w przestrzeniach publicznych Poznania, Poznań.

[16] Waliczek T. M., Zajiczek J.M. 1999. Kindergarden: Using computer technology to discover the benefits of children's gardening, Towards a new millenium in people - plant relationships. Univ.Technol., Sydney, Australia.

[17] Wilson E. O. 1993. Biophilia and the conservative ethic. The biophilia hypothesis, Washington D.C., Island Press, USA. 